\title{
Inhibition of compensatory ovarian hypertrophy in rats by antiserum to LH-RH
}

\author{
R. J. Remstein and S. Sorrentino, Jr \\ Department of Anatomy, University of Rochester, School of Medicine and Dentistry, \\ Rochester, New York 14642, U.S.A.
}

Unilateral ovariectomy of the rat causes compensatory hypertrophy of the other ovary (Heller, Heller \& Sevringhaus, 1942) which is believed to result from an initial decrease in peripheral oestrogen levels, followed by a concomitant increase in gonadotrophin release which restores the oestrogen concentration to the preoperative level (Benson, Sorrentino \& Evans, 1969). The phenomenon has been investigated mainly by inhibiting the compensatory ovarian hypertrophy by administration of sodium barbital (Sindgi \& Rao, 1973), aspirin (Goldman \& Poppens, 1973), oestradiol and oestriol (Peterson, Edgren \& Jones, 1962), or melatonin (Vaughan, Reiter \& Vaughan, 1971; Reiter, Vaughan \& Vaughan, 1972). The involvement of LH and FSH suggested an important role for LH-RH and this was investigated by injecting an antiserum to LH-RH and measuring the effect on compensatory ovarian hypertrophy in rats.

Female albino rats of the Holtzman strain, weighing 90-115 g and 28 days of age, were used. Food and water were available ad libitum, and the lighting schedule gave light from 06.00-18.00 hours. The rats were anaesthetized with ether for surgery and blood sampling. All data were analysed by Student's $t$ test and one-way analysis of variance.

The rats were randomly allocated to 4 groups on Day 0 , and at 08.00 hours $1.0 \mathrm{ml}$ blood was removed from the jugular vein. Group 1 contained unoperated control animals; rats in Group 2 were unilaterally ovariectomized and given a s.c. dose of $0.5 \mathrm{ml}$ normal rabbit serum (NRS); in Group 3 the animals were similarly unilaterally ovariectomized but received s.c. $0.5 \mathrm{ml}$ antiserum to LH-RH; the rats in Group 4 were given $0.5 \mathrm{ml}$ antiserum only. The undiluted antiserum was obtained from a rabbit immunized with LH-RH (Sorrentino \& Sundberg, 1975). A pilot study on the effects of the antiserum showed that a dose of $0.5 \mathrm{ml}$ would be most effective. On Day 2, $48 \mathrm{hr}$ after injection, another $1.0 \mathrm{ml}$ blood was taken and each animal injected with antiserum or NRS as on Day 0 . On Day 4, all the rats were weighed, killed by decapitation and bled. The remaining ovary (or ovaries) was removed and weighed, and pituitaries were dissected out and weighed.

Table 1. The effects (mean \pm S.D.) of two injections, $48 \mathrm{hr}$ apart, of $0.5 \mathrm{ml}$ antiserum to $\mathrm{LH}-\mathrm{RH}$ on compensatory ovarian hypertrophy in the rat

\begin{tabular}{|c|c|c|c|c|c|c|}
\hline Group & Treatment & $\begin{array}{l}\text { No. of } \\
\text { rats }\end{array}$ & $\begin{array}{l}\text { Wt of } \\
\text { first } \\
\text { ovary } \\
\text { (mg) }\end{array}$ & $\begin{array}{l}\text { Wt of } \\
\text { second } \\
\text { ovary } \\
\text { (mg) }\end{array}$ & $\begin{array}{l}\text { Uterine } \\
\text { wt } \\
(\mathrm{mg})\end{array}$ & $\begin{array}{c}\text { Pituitary } \\
\text { wt } \\
\text { (mg) }\end{array}$ \\
\hline 1 & $\begin{array}{l}\text { No operation } \\
\text { (control) }\end{array}$ & 9 & & $12 \cdot 4 \pm 2 \cdot 5^{*} \ddagger$ & $129 \pm 66 \dagger$ & $4 \cdot 4 \pm 0 \cdot 7$ \\
\hline 2 & $\begin{array}{l}\text { Unilateral } \\
\text { ovariectomy + NRS }\end{array}$ & 9 & $9 \cdot 9 \pm 2 \cdot 2$ & $17 \cdot 2 \pm 5 \cdot 9 \ddagger$ & $108 \pm 44$ & $4 \cdot 5 \pm 1 \cdot 0$ \\
\hline 3 & $\begin{array}{l}\text { Unilateral } \\
\text { ovariectomy + antiserum to } \\
\text { LH-RH }\end{array}$ & 9 & $10 \cdot 4 \pm 2.2$ & $12 \cdot 8 \pm 3 \cdot 0$ & $81 \pm 54$ & $4 \cdot 5 \pm 0 \cdot 6$ \\
\hline 4 & $\begin{array}{l}\text { No operation + antiserum to } \\
\text { LH-RH }\end{array}$ & 5 & & $9 \cdot 4 \pm 0.8^{*}$ & $67 \pm 18 \dagger$ & $4 \cdot 7 \pm 0.5$ \\
\hline
\end{tabular}

* Average of two ovaries, significantly different, $P<0.05$.

$\uparrow$ Significantly different, $P<0.05$.

‡ Significantly different, $P<0.05$. 
The results in Table 1 show that the antiserum to LH-RH significantly inhibited ovarian hypertrophy in operated animals, from $80 \pm 76$ (S.D.) to $22 \pm 15 \%(P<0.05)$, and reduced ovarian and uterine weight in unoperated animals.

These observations support the hypothesis that LH-RH is involved in the achievement of compensatory ovarian hypertrophy.

We thank Ms Marjorie Shoemaker for her excellent technical assistance; and the College of Arts and Sciences, University of Rochester for partial support of R.J.R. The work was supported by USPHS Grants AM-1 6577 and HD-07926, and Program Project NS-11642.

\section{References}

Benson, B., Sorrentino, S. \& Evans, J. (1969) Increase in serum FSH following unilateral ovariectomy in the rat. Endocrinology 84, 369-374.

Goldman, M. \& Poppens, C. (1973) Inhibition of unilateral compensatory hypertrophy in the rat by ingestion of aspirin. Toxic. appl. Pharmacol. 24, 159-161.

Heller, C., Heller, E. \& Sevringhaus, E. (1942) Does estrogen substitution materially inhibit pituitary gonadotropic potency? Endocrinology 30, 309316.

Peterson, D., Edgren, R. \& Jones, R. (1962) The blocking effect of various steroids in the hemicastrate rat. Am. Zool. 2, 547.

Reiter, R., Vaughan, M. \& Vaughan, G. (1972)
Melatonin action on the course of compensatory ovarian hypertrophy in the Swiss-Webster mouse. Int. J. Fert. 17, 59-62.

SrNDGI, S. \& RAo, M. (1973) Inhibition of ovarian compensatory hypertrophy by barbital sodium in hemispayed albino rats. Curr. Sci. 42, 173-174.

Sorrentino, S. \& SundberG, D. (1975) Measurement of plasma and hypothalamic luteinizing hormone releasing hormone in pregnant mare serum induced ovulating immature rats. Neuroendocrinology 17, 274-282.

Vaughan, M., ReITer, R. \& Vaughan, G. (1971) Effect of delaying melatonin injections on the inhibition of compensatory ovarian hypertrophy in mice. $J$. Endocr. 51, 787-788.

Received 15 April 1976 